\title{
Penerapan Model Inquiring Minds Want To Know Pada Tema 7 (Kepemimpinan) Upaya Meningkatkan Motivasi Dan Hasil Belajar Peserta Didik Kelas VI Semester Satu Tahun Pelajaran 2019/2020 di SD Negeri 30 Mataram
}

\author{
Rosalina \\ Guru Kelas VI SD Negeri 30 Mataram
}

\begin{abstract}
Abstrak. Penelitian ini bertujuan untuk mengetahui efektifitas penerapan model pembelajaran Inquiring Minds Want To Know dalam upaya meningkatkan motivasi dan hasil belajar Peserta Didik Kelas VI SD Negeri 30 Mataram. Manfaat penelitian ini adalah sebagai bahan kajian dan bahan temuan dalam pelaksanaan proses pembelajaran di kelas senyatanya. Bagi guru untuk meningkatkan kompetensi dalam proses pembelajaran dan bagi Peserta Didik untuk meningktakan motivasi belajar yang berdampak meningkatnya hasil belajar Peserta Didik. Penelitian ini dilaksanakan dua siklus, masing-masing siklus kegiatannya adalah; perencanaan, pelaksanaan, observasi dan refleksi. Hasil akhir tindakan pada siklus II menunjukkan bahwa hasil observasi guru memperoleh skor rata-rata $(4,79)$ dan hasil observasi Peserta Didik mencapai skor rata-rata $(4,46)$. Sedangkan dampak dari peningkatan motivasi belajar adalah meningkatnya perolehan hasil belajar Peserta Didik mencapai nilai rata-rata $(86,87)$, artinya indikator keberhasilan $(\geq 4,0)$ telah terlampaui. Karena indicator keberhasilan telah terbukti penelitian dinyatakan berhasil dan dihentikan pada siklus II.
\end{abstract}

\section{Kata Kunci : Motivasi dan Hasil Belajar - Inquiring Minds Want To Know.}

\section{PENDAHULUAN}

\section{Latar Belakang}

Salah satu model pembelajaran yang sederhana tetapi dapat membangkitkan motivasi belajar peserta didik dengan cara meminta mereka membuat perkiraan-perkiraan tentang sesuatu topic atau suatu pertanyaan. Biasanya peserta didik cenderung diam ketika diajarkan untuk membahas materi-materi yang belum terpecahkan pada pertemuan sebelumnya jika diminta untuk menjawab secara bersama-sama satu kelas. Upaya membangkitkan motivasi belajar dimaksud memerlukan strategi pembelajaran yang mengarah pada pembelajaran peserta didik aktif, inovatif, kreatif, efektif dan menyenangkan atau yang sering disebut dengan PAIKEM. Strategi PAIKEM ini dapat dipraktikkan melalui beberapa model pembelajaran seperti; Inquiring Minds Want To Know (Bangkitkan Minat), listening teams (Tim Pendengar), Guided More Talking (Catatan terbimbing) dan masih banyak lagi model pembelajaran yang mampu membangkitkan motivassi belajar peserta didik.
Proses pembelajaran di SD Negeri 30 Mataram selama ini masih cenderung menerapkan strategi pembelajaran guru sentris. Pembelajaran ini gurulah yang aktif, sementara peserta didik hanya duduk manis mendengarkan penjelasan guru, mencatat sampai habis terhadap aapa materi pelajaran yang diberikan oleh guru. Peserta didik sangat passif tidak ada inovatif dan tidak ada kreatif selama proses pembelajaran. Dampak yang dihasilkan yaitu rendahnya motivasi dan hasil belajar peserta didik di kelas VI semester satu tahun pelajaran 2019/2020 di SD Negeri 30 Mataram.

Rendahnya motivasi dan hasil belajar peserta didik kelas VI semester satu tahun pelajaran 2019/2020 yang dibuktikan dengan perolehan hasil pengamatan dan hasil belajar peserta didik pada kondisi awal masih belum mencapai KKM yang diharapkan adalah; 1) kurang sinkronnya antara strategi dan model pembelajaran bagi perkembangan psikologi peserta didik kelas VI SD Negeri 30 Mataram, 2) kurang gairah/tidak termotivasinya peserta didik mengikuti pelajaran, 3) belum tercapainya 
kriteria ketuntasan minimal (KKM) bagi peserta didik, dan 4) selama proses pembelajaran peserta didik terkesan acuh tak acuh, cuek, rebut di kelas, main $\mathrm{Hp}$, saling lempar kertas dan perilaku lain yang menyebabkan terganggunya kondusifitas dalam proses pembelajaran.

Banyak solusi yang bisa dilakukan oleh guru selaku peneliti yaitu dengan mengoptimalkan penerapan strategi dan model pembelajaran yang mengarah pada pola pembelajaran peserta didik aktif, inovatif, kreatif, efektif, dan menyenangkan (PAIKEM), diantaranya yaitu dengan penerapan model Inquiring Minds Want To Know (bangkitkan minat). Alas an memilih model Inquiring Minds Want To Know adalah; 1) mampu mendorong peserta didik untuk berinovasi selama proses pembelajaran sesuai dengan materi pelajaran yang disampaikan oleh guru, 2) muncul kreativitas (ide, gagasan) bagi peserta didik dalam mengolah dan menginformasikan kepada teman sejawat, 3) model pembelajaran ini sangat efektif bagi peserta didik untuk dapat meningkatkan hassil belajarnya, dan 4) bagi peserta didik model pembelajaran Inquiring Minds Want To Know ini dapat menciptakan suasana gembira, riang ria, serius santai sukses (3S).

Mengingat model pembelajaran Inquiring Minds Want To Know ini memiliki beberapa keunggulan, maka perlu pembuktian dengan cara melaksanakan Penelitian Tindakan Kelass (PTK) dengan judul "Penerapan Model Inquiring Minds Want To Know Pada Tema 7 (Kepemimpinan) Upaya Meningkatkan Motivasi Dan Hasil Belajar Peserta DDidik Kelas VI Semester Satu Tahun Pelajaran 2019/2020 di SD Negeri 30 Mataram".

Rumusan Masalah

: "apakah model pembelajaran Inquiring Minds Want To Know dapat meningkatkan motivasi dan hassil belajar peserta didik Kelas VI Semester Satu Tahun pelajaran 2019/2020 di SD Negeri 30 Mataram".

\section{Tujuan penelitian}

Jurnal Ilmu Sosial dan Pendidikan
Untuk mengetahui sejauh mana efektivitas penerapan model pembelajaran Inquiring Minds Wantt To Know dalam upaya meningkatkan motivasi dan hasil belajar Peserta didik Kelas VI SD Negeri 30 Mataram.

\section{Manfaat Penelitia}

- Bermanfaat bagi guru selaku peneliti dalam rangka melaksanakan proses pembelajaran yang kontekstual melalu penerapan model pembelajaran Inquiring Minds Want To Know di kelas senyatanya serta dalam upaya perwujudan pembelajaran yang aktif, inovatif, kreatif, efektif, dan menyenangkan (PAIKEM) sehingga motivasi Peserta didik dapat ditingkatkan.

- Bagi Peserta didik sangat bermanfaat dalam upaya peningkatan motivasi dan hasil belajar yang berdampak meningkatnya prestasi belajar Peserta didik.

\section{KAJIAN PUSTAKA \\ Kerangka teoritis \\ Motivasi}

Motivasi dapat diartikan serangkaian usaha menyediakan kondisi-kondisi tertentu, sehingga seorang itu mau dan ingin melakukan sesuatu dan bila ia tidak suka, maka akan berusaha meniadakan dan meyalahkan perasaan tidak suka itu (Sardiman, 2007). Pendapat lain mengatakan bahwa motivasi dan hasil belajar adalah merupakan faktor fisik yang bersifat non intelektual (Hil,2002). Peserta didik yang memiliki motivasi yang kuat, akan mempunyai banyak energy untuk melakukan kegiatan (Sardiman, 2007). Jika guru memiliki suatu kejelasan ide mengenai arah program pembelajaran Peserta didik dapat diberi kebebasan untuk menyesuaikan bahan dan program tersebut pada suatu arah dan konteks dari pilihannya sendiri (Nurhaadi, 2003). Jika Peserta didik berpartissi dalam pembuatan perencanaan pengalaman belajarnya sendiri, motivasi Peserta didik akan meningkat dan terjaga dengan baik.

Dalam penelitian ini, motivasi dan hasil belajar yang akan diukur adalah pola belajar 
Peserta didik dalam proses pembelajaran di kelas yaitu sikap antusias terhadap materi yang diajarkan. Prilaku untuk anak bekerjasama dalam kelompok kecil, keaktifan dalam melaksanakan kerjasama dalam kelompok, kemampuan tiap-tiap Peserta didik untuk menjawab pertanyaan dari teman sejawat maupun yang berasal dari guru mata pelajaran, dan yang terakhir adalah kemampuan Peserta didik untuk memanage waktu yang diberikan oleh guru untuk masing-masing kelompok.

\section{Hasil belajar}

Mukhtar (2003:54) mengatakan bahwa pengertian hasil belajar tidak dapat dipisahkan dan apa yang terjadi dalam aktifitas pembelajaran baik di kelas maupun diluar kelas. Apa yang dialami oleh Peserta didik dalam proses pengembangan kemampuannya merupakan apa yang diperoleh dalam belajar dan pengalaman tersebut pada akhirnya dipengaruhi oleh beberapa faktor diantaranya keadaan kognitif, afektif dan psikomotornya pada waktu belajar. Kualitas pengajaran yang diterimanya dan cara pengelolaan proses interaksi yang dilakukan oleh guru.

Masalah evaluasi hasil belajar meliputi alat ukur yang digunakan, cara menggunakan, cara penilaian dan evaluasinya (Harus Rasid dan Mansur, 2008:9). Evaluasi hasil belajar yang berhubungan dengan tugas guru rutin dilakukan evaluasi hasil, yang juga dijadikan umpan balik, evaluasi hasil bertujuan menilai apakah hasil belajar dicapai sesuai dengan tujuan (Lukmanul Hakim, 2008:165). Pakar pendidikan lain mendefinisikan bahwa yang dimaksud hasil belajar adalah perubahan perilaku secara keseluruhan bukan salah satu aspek potensi kemanusiaan saja (Supriyono, 2009:19). Berbeda dengan pendapatnya Bloom (Dalam Sumiati danAska, 2008). Hasil belajar mencakup kemampuan kognitif, afektif, dan psikomotorik. Jadi pendapat ini mengisyaratkan bahwa haasil belajar Peserta didik harus diukur dengan tes tertulis, tes sikap, dan kemampuan skiil secara nyata selama proses pembelajaran di kelas senyatanya.
Dalam penelitian ini yang dimaksud dengan hasil belajar adalah tes ulangan harian yang dilaksanakan secara tertulis pada akhir pembelajaran.

\section{Inquiring Minds Want To Know}

Teknik sederhana ini dapat membangkitkan keingintahuan peserta didik dengan meminta mereka membuat perkiraanperkiraan tentang suatu topic atau suatu pertanyaan. Biasanya peserta didik cenderung diam ketika diajak untuk membahas materimateri yang belum terpecahkan pada pertemuan sebelumnya jika diminta untuk menjawab secara bersama-sama satu kelas.

\section{Langkah-langkah}

Buat satu pertanyaan tentang materi pelajaran yang dapat membangkitkan minat peserta didik untuk mengetahui lebih lanjut atau mau mendiskusikannya dengan teman. Pertanyaan tersebut harus dibuat yang sekiranya hanya diketahui oleh sebagian kecil peserta didik. Misalnya adalah:

- Pengetahuan sehari-hari ("Mengapa harga BBM harus naik?")

- Bagaimana ("Menurut prinsip-prinsip andragogi, bagaimana seharusnya seorang pengajar memperlakukan peserta didiknya?")

- Definisi (“Apakah tujuan pembelajaran itu?”)

- Ide pokok ("Menurut anda, apa yang dibahas dalam topic ini?”)

- Cara kerja sesuatu (“Apa yang menyebabkan concept map dapat dipahami oleh orang lain?")

- Produk/Hasil ("Menurut anda apa yang akan dihasilkan oleh pelatihan ini?")

- Solusi ("Apa jalan keluarnya jika tidak mau mengerjakan tugas-tugas yang diberikan oleh seorang pelajar?")

Anjurkan peserta didik untuk menjawab apa saja sesuai dengan dugaan mereka. Gunakan kata-kata; coba perkirakan, apa kira-kira? Dan lain-lain

Jangan member jawaban secara langsung. Tamping semua dugaan-dugaan. Biarkan peserta didik bertanya-tanya tentang jawaban yang benar. 
Gunakan pertanyaan tersebut sebagai jambatan untuk mengajarkan apa yang akan anda ajarkan kepada peserta didik. Jangan lupa beri jawaban yang benar di tengah-tengah anda menyampaikan pelajaran.

Hipotesis Tindakan.

Penerapan pendekatan Inquiring Minds Want To Know dapat meningkatkan motivasi dan hasil belajar Peserta didik Kelas VI SD Negeri 30 Mataram semester satu tahun pelajaran 2019/2020.

\section{METODE PENELITIAN}

\section{Setting Penelitian}

Penelitian tindakan kelas (PTK) ini akan dilaksanakan di Kelas VI SD Negeri 30 Mataram semester satu Tahun pelajaran 2019/2020, dengan jumlah Peserta didik sebanyak 34 Orang.

\section{Faktor yang Diteliti}

- Faktor Guru: yaitu dengan mengganti cara guru membuat Rencana Pelaksanaan Pembelajaran (RPP) dan pelaksanaannya dalam pembelajaran di kelas senyatanya dengan menerapkan model pembelajaran Inquiring Minds Want To Know dalam upaya meningkatkan motivasi dan hasil belajar Peserta didik Kelas VI SD Negeri 30 Mataram.

- Faktor Peserta didik: yaitu peningkatan motivasi dan hasil belajar Peserta didik yang terlihat pada perilaku Peserta didik selama diskusi kelompok, dan pada saat mengerjakan tes tertulis.

\section{Rencana Tindakan}

Kegiatan nyata di Kelas VI yaitu melaksanakan proses pembelajaran dengan menerapkan model pembelajaran Inquiring Minds Want To Know dalam upaya meningkatan motivasi dan hasil belajar Peserta didik kelas VI SD Negeri 30 Mataram semester satu tahun pelajaran 2019/2020. Tindakan nyata yang dilakukan oleh guru selaku peneliti adalah dengan menggunakan siklus. Gambaran siklus dalam penelitian ini adalah sebagai berikut:

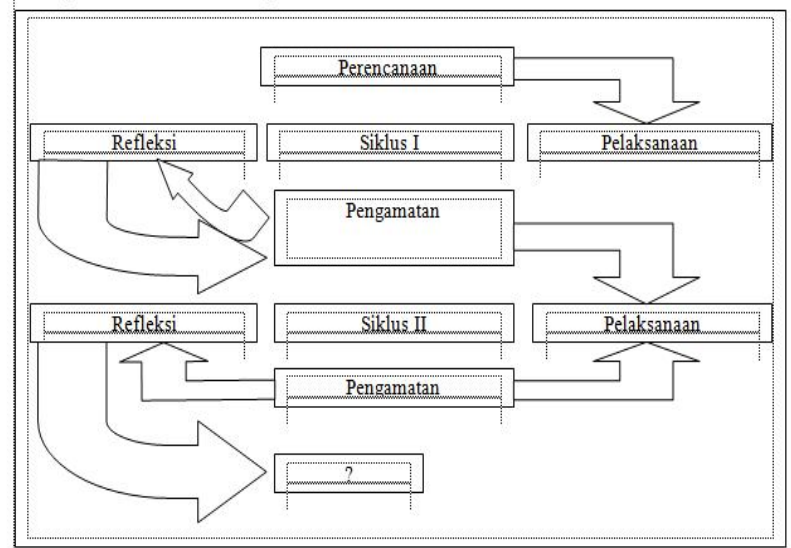

Setiap siklus selama penelitian ini berisi 4 (empat) tahapan yaitu: 1) Perencanaan (Planning), 2) Pelaksanaan (Action), 3) Observasi (Observation), dan 4) Refleksi (Reflection).

\section{Siklus Tindakan}

\section{SIKLUS I}

\section{1) Tahap Perencanaan (Planning)}

1. Pada tahapan ini guru selaku peneliti melakukan kegiatan-kegiatan sebagai berikut:

2. Menyusun Rencana Pelaksanaan Pembelajaran (RPP) dengan skenario sesuai dengan aturan main model pembelajaran Inquiring Minds Want To Know.

3. Menyiapkan sumber, bahan, dan semua alat yang digunakan dalam penelitian.

4. Menyusun/membuat lembar observasi guru dan lembar observasi Peserta didik.

5. Menyusun alat evaluasi.

2) Tahap Pelaksanaan (Action)

Pada tahapan ini guru selaku peneliti melaksanakan proses pembelajaran dengan penerapan model pembelajaran Inquiring Minds Want To Know dengan skenario sebagai berikut:

\section{Pertemuan I}

1. Guru membagi Peserta didik menjadi 8 (delapan) kelompok kecil, masing-masing kelompok beranggotakan 4-5 orang Peserta didik. 
2. Masing-masing kelompok diberikan tugas/soal untuk dipecahkan bersama dalam kelompok,

\section{Pertemuan II}

3. Masing-masing kelompok kemudian mempresentasikan hasil kerja kelompoknya di depan kelas

4. Tes tertulis

\section{3) Tahap Observasi (Observation)}

Pada tahapan observasi ini diadakan pengamatan oleh observer untuk mengamati :

1. Observasi guru :

Dilakukan oleh pengawas mata pelajaran observer sekaligus sebagai pembimbing guru dalam melaksanakan Penelitian Tindakan Kelas (PTK).

2. Observasi Peserta didik :

Dilaksanakan oleh guru mata pelajaran sekaligus sebagai peneliti dalam Penelitian Tindakan Kelas (PTK) pada kegiatan diskusi kelompok.

\section{4). Tahap Refleksi (Reflection)}

Pada tahapan ini guru selaku peneliti melakukan kegiatan akhir dari hasil penelitian pada siklus yang bersangkutan meliputi :

1. Renungan hasil perolehan data

2. Pengolahan dan analisa data hasil penelitian

3. Mencocokkan hasil analisa data dengan indikator keberhasilan

4. Rencana perbaikan dan tindak lanjut

SIKLUS II

Pada siklus ini semua kegiatan dan tahapan selama penelitian adalah sama, sifatnya mengulang dan memperbaiki terhadap tindakan yang masih memerlukan penyempurnaan dan pembenaran sebagaimana mestinya.

\section{Data dan Cara Pengambilannya. \\ Sumber Data}

Yang menjadi sumber data dalam penelitian tindakan kelas (PTK) ini adalah semua Peserta didik Kelas VI semester satu tahun pelajaran 2019/2020 di SD Negeri 30 Mataram dan semua tim peneliti.

\section{Jenis Data}

- Jenis data yang berasal dari guru selaku peneliti
1). Data tentang Rencana Pelaksanaan Pembelajaran (RPP)

2). Data Pelaksanaan Pembelajaran

- Jenis data yang berasal dari Peserta didik :

1). Data kemajuan motivasi dari Peserta didik

2). Data hasil belajar Peserta didik

\section{Cara Pengambilan data}

- Data kegiatan pembelajaran diambil dari RPP yang dibuat oleh guru dan lembar observasi pelaksanaan model pembelajaran Inquiring Minds Want To Know

- Data kemajuan motivasi dan hasil belajar; diambil dari lembar observasi selama diskusi kelompok.

- Data kemajuan hasil belajar; diambil dari nilai pada saat tes tertulis yang dilaksanakan pada akhir proses pembelajaran.

\section{Indikator Keberhasilan dan Teknik analisa} data

Teknik analisa data

Untuk menganalisis data akan dilakukan melalui analisis deskriptif kuantitatif melalui pendataan, analisis dan pembahasan terhadap data yang diperoleh dengan mencocokkan tingkat keoptimalan terhadap capaian indikator keberhasilan yang ada.

\section{Indikator Keberhasilan}

- guru telah dinyatakan berhasil melaksanakan proses pembelajaran dengan pendekatan Inquiring Minds Want To Know, bila telah mencapai skor rata-rata $\geq$ 4, 00

- Motivasi dan hasil belajar Peserta didik Kelas VI dinyatakan telah meningkat jika $\geq$ $85 \%$ dari jumlah Peserta didik telah memperoleh skor perolehan skor rata-rata $\geq 4,0$, hasil belajar dinyatakan meningkat jika $\geq 85 \%$ dari jumlah Peserta didik memperoleh nilai rata-rata $\geq 75,00$ (Sesuai KKM)

\section{HASIL DAN PEMBAHASAN Laporan Hasil}




\section{DESKRIPSI SIKLUS I}

\section{Tahap Perencanaan}

Pada tahapan ini yang telah dilakukan oleh guru selaku peneliti adalah; 1) menyusun RPP dengan skenario pembelajaran Inquiring Minds Want To Know, 2) telah berhasil menyiapkan alat, sumber, bahan yang diperlukan dalam penelitian, 3) berhasil menyusun instrument observasi guru dan instrument observasi Peserta didik, dan 4) menyusun alat evaluasi.

\section{Tahap Pelaksanaan}

1. Guru membuat satu pertanyaan tentang materi pelajaran yang dapat membangkitkan minat peserta didik untuk mengetahui lebih lanjut atau mau mendiskusikannya dengan teman.

2. Berikan waktu bagi peserta didik untuk menjawab apa saja sesuai dengan dugaan mereka. Gunakan kata-kata; coba perkirakan, apa kira-kira? Dan lain-lain

3. Jangan memberi jawaban secara langsung. Tamping semua dugaan-dugaan. Biarkan peserta didik bertanya-tanya tentang jawaban yang benar. Gunakan pertanyaan tersebut sebagai jambatan untuk mengajarkan apa yang akan anda ajarkan kepada peserta didik. Jangan lupa beri jawaban yang benar di tengah-tengah anda menyampaikan pelajaran

Selama kerja kelompok, guru melakukan penyeimbangan peningkatan/kemajuan motivasi dan hasil belajar Peserta didik yang meliputi aspek antusias, kerjasama, aktifitas, kemampuan menjawab, dan efektifitas waktu dan hasil tes tertulis.

\section{Tahap Observasi}

Observasi guru pertemuan I $(3,29)$ dan pertemuan II $(3,64)$, observasi peserta didik pertemuan I $(3,25)$ dan pertemuan II $(3,59)$. Hasil tugas dan tes tertulis dari masing-masing peserta didik memperoleh nilai rata-rata sebesar $(69,38)$ dan $(69,94)$.

\section{Tahap Refleksi}

Jurnal Ilmu Sosial dan Pendidikan
Pada tahapan ini peneliti melakukan kegiatan refleksi sebagai dampak dari perolehan data hasil observasi guru, observasi Peserta didik, serta rata-rata nilai tes tertulis sebagai berikut:

1. Renungan data hasil perolehan data pada siklus I

2. Pengolahan data hasil observasi guru, Peserta didik dan tes tertulis.

3. Mencocokkan hasil yang ada dengan Indikator keberhasilan.

4. Merencanakan perbaikan terhadap jenis tindakan yang menyebabkan belum tuntas Indikator keberhasilan. Oleh karena Indikator keberhasilan belum terbukti maka penelitian dilanjutkan ke siklus II.

\section{DESKRIPSI SIKLUS II}

\section{Tahap Perencanaan}

Pada tahapan ini jenis kegiatan yang dilakukan masih mengacu pada kegiatan siklus I, bedanya hanya terjadi perbaikan seperlunya yaitu: 1) penyusunan RPP dengan mengacu pada model pembelajaran Inquiring Minds Want To Know dan penyempurnaan pada bagian skenario pembelajaran, 2) menyiapkan alat, sumber, bahan yang diperlukan dalam proses tindakan dikelas senyatanyan, 3) menyiapkan lembar observasi guru dan lembar observasi Peserta didik sebagaimana pada siklus I, 4) menyiapkan alat evaluasi sebagaimana yang telah dibuat pada siklus I.

\section{Tahap Pelaksanaan}

Secara umum tahapan pelaksanaan proses pembelajaran pada siklus II ini masih mengacu pada pelaksanaan proses pembelajaran sebelumnya. Pemecahan yang dilakukan pada proses pembelajaran ini adalah: 1) pelaksanaan proses diskusi kelompok kecil lebih dioptimalkan, 2) pelaksanaan pembimbingan kelompok sekaligus observasi Peserta didik lebih di efektifkan. Utamanya pengamatan Peserta didik yang termotivasi, yang kurang motivasi, Peserta didik yang tidak termotivasi, dengan harapan proses analisa data lebih signifikan, 3)laporan hasil kerja kelompok yang dibuat secara individu lebih difokuskan, dan 4) pelaksanaan tes tertulis yang merupakan dari 
peningkatan motivasi dan hasil belajar Peserta didik lebih diperketat.

\section{Tahap Observasi}

Observasi guru pertemuan I $(4,50)$ dan pertemuan II $(4,79)$, observasi peserta didik pertemuan I $(4,16)$ dan pertemuan II $(4,46)$. Hasil tugas dan tes tertulis dari masing-masing peserta didik memperoleh nilai rata-rata sebesar $(87,35)$ dan $(86,38)$.

\section{Tahap Refleksi}

1. Renungan atas perolehan data hasil observasi guru, observasi Peserta didik, dan hasil tes tertulis sebagai dampak dari peningkatan motivasi dan hasil belajar Peserta didik di kelas senyatanya.

2. Pengolahan data hasil observasi guru, observasi Peserta didik dan tes tertulis

3. Mencocokkan perolehan data hasil tindakan dengan Indikator keberhasilan yang telah ditetapkan.

4. Guru memberikan hadiah/reward kepada semua Peserta didik Kelas VI atas keberhasilannya dalam upaya meningkatkan motivasi dan hasil belajar yang berdampak terhadap perolehan hasil belajar sesuai dengan KKM yang telah ditetapkan.

\section{PEMBAHASAN}

\section{SIKLUS I}

\section{Tahap Perencanaan}

Peneliti menyusun RPP dengan skenario penerapan pendekatan Inquiring Minds Want To Know, menyiapkan alat, sumber, bahan yang diperlukan dalam proses pembelajaran, menyusun instrument observasi guru maupun instrument observasi Peserta didik mengalami beberapa kendala, tetapi setelah berkonsultasi dan meminta petunjuk dari pembimbing, kendala yang dihadapi pun dapat diatasi dengan baik.

\section{Tahap Pelaksanaan}

\section{Pertemuan I}

1. Guru membagi Peserta didik menjadi 8 (delapan) kelompok kecil, masing-masing kelompok beranggotakan 4-5 orang Peserta didik.
2. Masing-masing kelompok diberikan tugas/soal untuk dipecahkan bersama dalam kelompok,

\section{Pertemuan II}

3. Masing-masing kelompok kemudian mempresentasikan hasil kerja kelompoknya di depan kelas

Kegiatan pembelajaran diakhiri dengan tes tertulis, hal ini dimaksudkan untuk mengetahui dampak positif dari peningkatan motivasi dan hasil belajar Peserta didik Kelas VI SD Negeri 30 Mataram semester satu tahun pelajaran 2019/2020 dengan penerapan pendekatan Inquiring Minds Want To Know. Asumsi bila motivasi dan hasil belajar meningkat maka akan berdampak meningkatnya hasil belajar Peserta didik.

\section{Tahap Observasi}

Observasi guru memperoleh skor rata-rata pertemuan I $(3,29)$ pertemuan II $(3,64)$, Hasil observasi Peserta didik dalam upaya peningkatan motivasi dan hasil belajar Peserta didik Kelas VI semester satu tahun pelajaran 2019/2020 di SD Negeri 30 Mataram diperoleh skor rata-rata pertemuan I $(3,25)$ pertemuan II $(3,59)$. Dampak dari peningkatan motivasi/belum meningkatnya motivasi dan hasil belajar Peserta didik salah satunya dengan hasil tugas dan tes tertulis yang materinya hanya sekitar yang diajarkan pada saat itu juga, diperoleh nilai rata-rata $(69,38)$ dan $(69,94)$ kategori cukup.

\section{Tahap Refleksi}

Hasil analisa data peningkatan motivasi dan hasil belajar pada siklus I ini $(3,64)$ sedangkan yang diminta dalam Indikator keberhasilan $(\geq 4,0)$, ini artinya belum berhasil.

Karena Indikator keberhasilan belum tercapai, penelitian tindakan kelas (PTK) dilanjutkan ke siklus II dengan harapan optimalisasi penerapan strategi pembelajaran dengan pendekatan Inquiring Minds Want To Know dapat meningkatkan motivasi dan hasil belajar Peserta didik Kelas VI semester satu 
tahun pelajaran 2019/2020 di SD Negeri 30 Mataram.

\section{SIKLUS II}

\section{Tahap Perencanaan}

Peneliti menyusun Rencana Pelaksanaan Pembelajaran (RPP) dengan memperhatikan kesalahan-kesalahan pada siklus I. peneliti lebih memfokuskan tentang Rencana strategi jitu sehingga proses pembelajaran dengan pendekatan Inquiring Minds Want To Know dapat terelaisasi dengan baik, karenanya dalam penyusunan skenario benar-benar dirinci dari tiap aspek pada proses pembelajaran dengan Inquiring Minds Want To Know.

Sebelum proses pembelajaran dilaksanakan, peneliti menyiapkan semua alat, bahan, dan segala sesuatunya sehingga dalam pelaksanaan proses pembelajaran berjalan sesuai dengan skenario yang telah direncanakan. Agar proses pembelajaran dapat teratasi maka peneliti juga menyiapkan lembar observasi guru dan lembar observasi Peserta didik sebagai tolak ukur ketercapaian peningkatan motivasi dan hasil belajar Peserta didik Kelas VI SD Negeri 30 Mataram.

\section{Tahap Pelaksanaan}

Pada tahap pelaksanaan di siklus II ini pada dasarnya masih mengacu pada pelaksanaan siklus I, yaitu penerapan pendekatan Inquiring Minds Want To Know. Bedanya pada siklus ini lebih dioptimalkan.

\section{Tahap Observasi}

Pada siklus II ini hasil observasi memperoleh skor rata-rata pertemuan I $(4,50)$ pertemuan II $(4,79)$ sementara Indikator keberhasilan yang diharapkan $(\geq 4,0)$, ini artinya hasil perolehan data telah mengalami peningkatan karena Indikator keberhasilan telah terlampaui. Upaya meningkatkan motivasi dan hasil belajar Peserta didik Kelas VI semester satu tahun pelajaran 2019/2020 di SD Negeri 30 Mataram diperoleh skor rata-rata pertemuan I $(4,16)$ pertemuan II $(4,46)$, sementara Indikator keberhasilan yang telah diharapkan adalah $(\geq 4,0)$, ini artinya perolehan skor ratarata telah melampaui dari Indikator keberhasilan. Sebagai tolak ukur keberhasilan proses pembelajaran adalah hasil belajar Peserta didik meningkat, dari data hasil perolehan nilai rata-rata nilai tugas dan tes tertulis adalah $(87,35)$ dan $(86,38)$ berarti mengalami peningkatan yang signifikan.

\section{Tahap Refleksi}

Hasil analisa data peningkatan motivasi dan hasil belajar Peserta didik pada siklus II adalah $(4,46)$ sedangkan Indikator keberhasilan $(\geq 4,0)$. Ini artinya pada siklus II hasilnya telah melampaui Indikator keberhasilan, sedangkan hasil belajar rata-rata $(86,87)$ dari indikator keberhasilan $\geq 75,00$, artinya telah melampaui indikator keberhasilan yang ditentukan.

Karena Indikator keberhasilan telah terbukti, maka tidak perlu ada upaya perbaikan dan penyempurnaan. Pendekatan Inquiring Minds Want To Know telah mampu meningkatkan motivasi dan hasil belajar Peserta didik yang ditandai dengan tercapainya Indikator keberhasilan dan terjadinya peningkatan hasil belajar Peserta didik. "Penelitian Tindakan Kelas (PTK) dihentikan pada siklus II dengan hasil memuaskan."

\section{SIMPULAN DAN SARAN}

\section{Simpulan}

Data komulatif dari hasil penelitian tindakan kelas (PTK) dari siklus I ke Siklus II adalah sebagai berikut:

\begin{tabular}{|c|c|c|c|c|c|c|c|}
\hline \multirow{2}{*}{ No } & \multirow{2}{*}{ Jenis Kegiatan } & \multirow{2}{*}{$\begin{array}{c}\text { Indikator } \\
\text { keberhasilan }\end{array}$} & \multicolumn{2}{|c|}{ Siklus I } & \multicolumn{2}{|c|}{ Siklus II } & \multirow{2}{*}{ Keterangan } \\
\hline & & & I & II & I & II & \\
\hline 1. & Observasi Guru & $\geq 4,00$ & 3,29 & 3,64 & 4,50 & 4,79 & Meningkat \\
\hline 2. & Observasi Peserta didik & $\geq 4,00$ & 3,25 & 3,59 & 4,16 & 4,46 & Meningkat \\
\hline 3. & Nilai Tugas Individusl & $\geq 75,00$ & \multicolumn{2}{|c|}{69,38} & \multicolumn{2}{|c|}{87,35} & Meningkat \\
\hline 4. & Tes tertulis & $\geq 75,00$ & \multicolumn{2}{|c|}{69,94} & \multicolumn{2}{|c|}{86,38} & Meningkat \\
\hline
\end{tabular}

Penerapan pendekatan Inquiring Minds Want To Know sangat efektif upaya untuk meningkatkan motivasi dan hasil belajar Peserta didik Kelas VI semester satu tahun pelajaran 2019/2020 di SD Negeri 30 Mataram. Fakta telah menunjukkan perolehan rata-rata skor motivasi dan hasil belajar Peserta didik pada siklus I $(3,59)$, sedangkan pada siklus II $(4,46)$, hasil belajar siklus I $(69,66)$ dan Siklus II $(86,87)$ sudah melampaui Indikator keberhasilan yang ditetapkan. Penelitian dinyatakan "berhasil" dan dihentikan pada siklus II. 


\section{Saran-Saran}

Disarankan kepada guru sejawat untuk melaksanakan Penelitian Tindakan Kelas (PTK) dalam upaya untuk meningkatkan motivasi dan atau hasil belajar Peserta didik sesuai dengan mata pelajaran masing-masing.

Disarankan kepada para semua Peserta didik Kelas VI SD Negeri 30 Mataram untuk membiasakan belajar dengan pendekatan yang kontekstual utamanya strategi yang mampu membangkitkan motivasi dan hasil belajar Peserta didik yang dampaknya hasil belajar dapat ditingkatkan seperti yang diharapkan

\section{DAFTAR PUSTAKA}

Arikunto, s. 2009, Penelitian Tindakan Kelas, Jakarta : Bumi Aksara.

Harun Rasyid dan Mansur, 2008, Penilaian Hasil Belajar, Bandung : CV Wacana Prima.

Ismail,2017, Strategi Pembelajaran Aktif, Semarang:Rosail Media Group.

Lukmanul A, 2008, Perencanaan Pembelajaran, Bandung : CV Wacana Prima.

Mukhtar, 2003, Prosedur Penilaian, Jakarta : Rineka Cipta.

Nurhadi, 2003, Yasin ,B dan Sendule.A, 2003, Kontekstual dan Penerapannya dalam KBK, Malang : Unitipetas Negeri Malang.

Robert E Slavin, 2010, Cooperative Learning Teori, riset dan Praktik, Bandung : Nusa Media.

Sardiman, 2007, Indikator Dan Motivasi dan hasil belajar Mengajar, Jakarta : Raja Grafindo Perkasa.

Supriono, 2009, Cooperative Learning Teori dan Aplikasi PAIKEM, Yogyakarta : Pustaka Pelajar. 